\title{
Agricultural Transition in Russia, Central Asia, and Eastern Europe: Ten Lessons for Venezuela
}

Karen Brooks 


\section{CONTENTS}

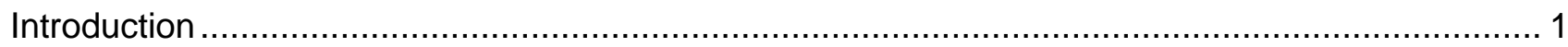

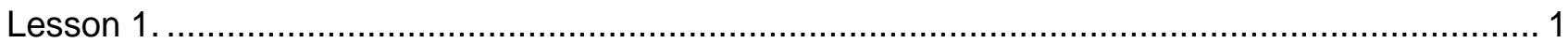

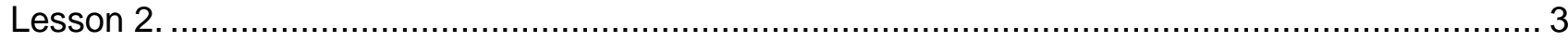

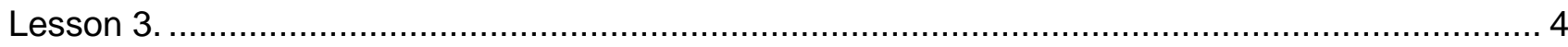

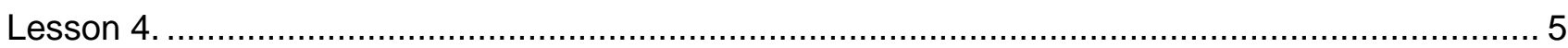

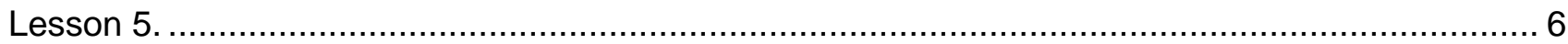

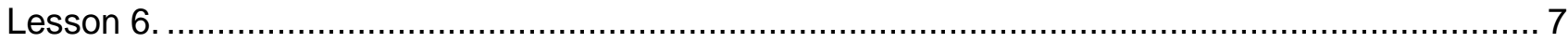

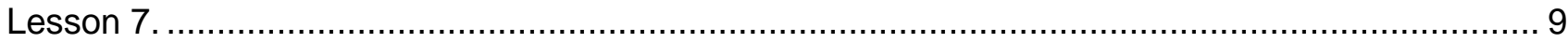

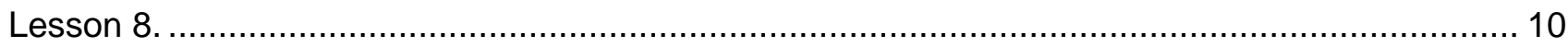

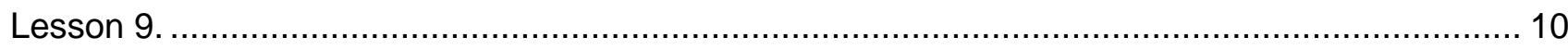

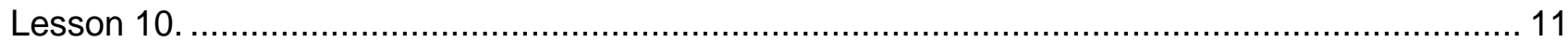

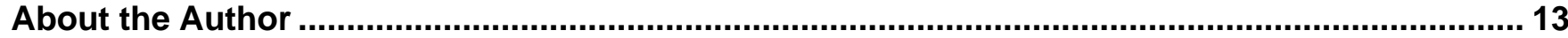

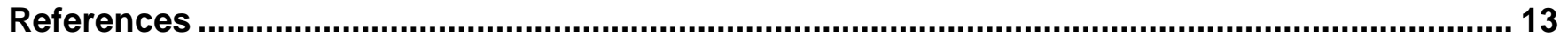

\section{FIGURES}

Figure 1: Share of Agriculture in Russian GDP during the transition.......................................... 2

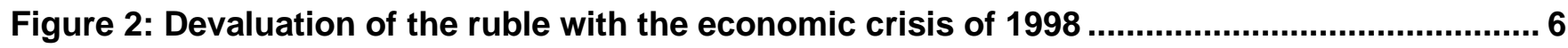

Figure 3: Russian Production, Inputs, and TFP during the transition .......................................... 7 


\section{Introduction}

Thirty years have elapsed since the fall of communist governments in Eastern Europe and the Soviet Union. The collapse of political structures took with it regimes of highly administered management of agri-food systems. The shift from state management to markets has been generally known as the agricultural transition. The term is most frequently used in reference to the former Soviet Union and Eastern Europe, but key features of a move from dominant state intervention to greater reliance on markets characterized reforms in China after 1978, Vietnam in 1986 and thereafter, and many countries in Africa south of the Sahara during the years of structural adjustment in the 1990s. The policy reforms that constitute an agricultural transition are intrinsically difficult and made even more so when undertaken under conditions of crisis-induced chaos. Lessons from countries that have undergone the process might be of use, either as guidance or cautionary notes, to leaders and civil society groups in countries such as Venezuela that may be embarking on a transition or swept into one by circumstance. The paragraphs below attempt to summarize lessons from the early transition in Russia, Central Asia, and Eastern Europe in the 1990s.

\section{Lesson 1.}

\section{Context matters, and lessons of transition do not necessarily generalize.}

At the outset of the transition in Eastern Europe in 1990, many foreign observers and advisors anticipated that agriculture would be a bright spot, providing an early supply response and absorbing labor released from shuttered industrial enterprises. They expected this based on the experience of China, for which the adoption of the household responsibility system after 1978 and reforms in price and marketing policies in the 1980s led to full-scale decollectivization and spectacular agricultural growth for two decades. The breakup of large collective and state farms in Eastern Europe and later in the former Soviet Union was expected to deliver incentive effects sufficient to fuel a supply response. That this did not happen caused consternation, particularly in the community of international advisors, and a loss of valuable time in framing strategies of assistance. In noting this misperception in October 1991, I wrote, "The agricultural transition is approximately a year and a half old, if we date its start from the Polish big bang of January 1990. Like many a recalcitrant toddler, it refuses to behave as expected (Brooks 1991)."

The misapplication of lessons of China's experience to Eastern Europe and subsequently to the Soviet Union occurred because key elements of the contextual difference were not sufficiently understood at the time. China's pre-reform regime imposed institutional barriers to efficiency in the form of collectivized agriculture and heavy taxes through administered prices and marketing orders. In contrast, by the 
late 1980s in both Eastern Europe and the Soviet Union, agriculture was highly subsidized through direct budgetary transfers to keep consumer prices low, through input subsidies, and through high producer prices (Swinnen and Rozelle, 2006; Rada et. al., 2017). The abrupt withdrawal of these subsidies with the transition led to a fall in the estimated PSE in the Soviet Union from a positive $60 \%$ in late 1991 to a negative $80 \%$ in mid- 1992 (Brooks and Gardner, 2004). An alternative view of the degree of subsidization can be seen in East German agricultural accounts when East German agriculture was valued in West German prices at a DM exchange rate of 1:1 for East and West. Total East German agricultural production in the value of 32 billion DM yielded a financial loss of 10 billion DM (Boese, C. et.al. quoted in Koester and Brooks 1997). This loss was invisible in the distorted prices prior to the transition, and covered by implicit subsidies to agricultural production, with likely additional subsidization of consumers. With the price reforms of the transition, the loss became visible and unavoidable. Rather than increasing supply, as did China's farmers, their counterparts in the Soviet Union and Eastern Europe cut back on area planted and inputs in response to the sharp deterioration of incentives. Output contracted sharply, both absolutely, and as a share of Russia's plummeting GDP, as shown in Figure 1.

\section{Figure 1: Share of Agriculture in Russian GDP during the transition}

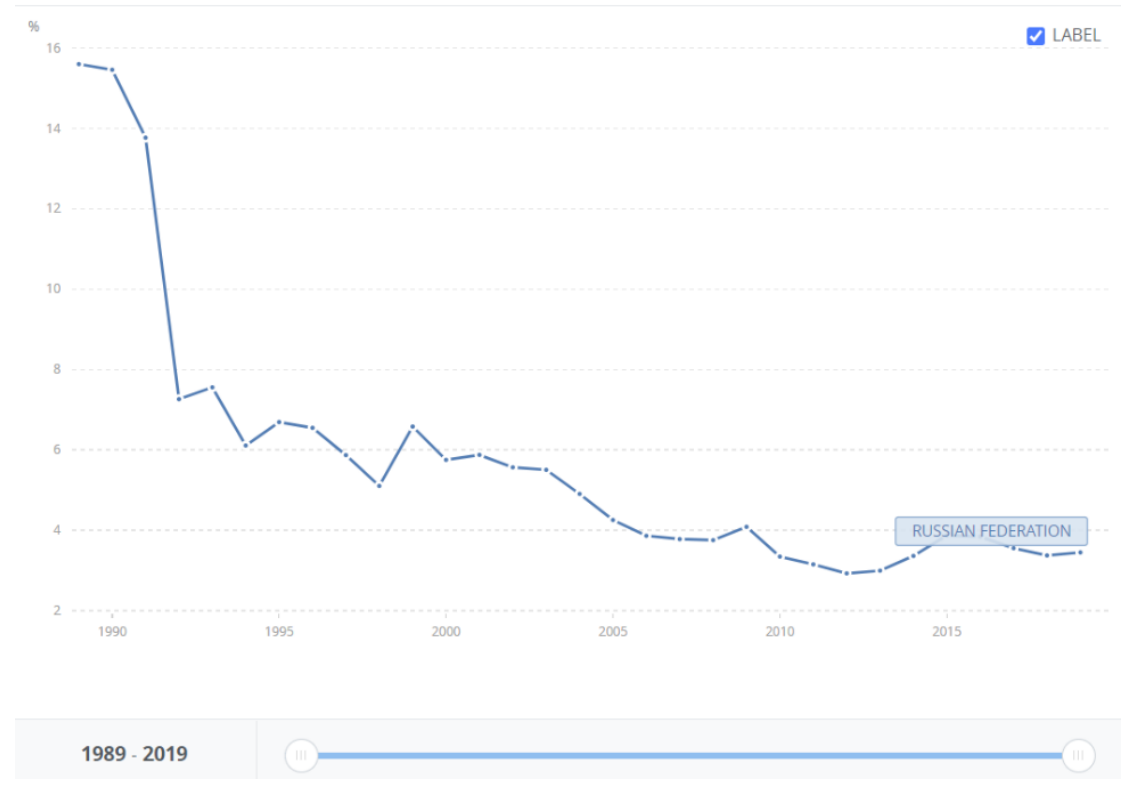

Source: WDI

Whether agriculture responds positively or negatively to the changes embodied in a transition depends crucially on the entirety of the incentive regime prior to the change, as well as the speed and mechanisms through which reforms are introduced. Lessons of experience should therefore be considered with full knowledge of the similarities and differences in context, and transparency about assumptions of generalizability. 


\section{Lesson 2.}

Price liberalization in Russia proceeded more slowly and unevenly than anticipated. Release of administered prices preceded privatization and restructuring of the off-farm segments of the agri-food system, muting the transmission of price signals. Regional authorities retained significant control over prices despite liberalization at the federal level.

Russia's price liberalization of January 1992 is often referred to as a big bang, or shock therapy in recognition of its suddenness and the magnitude of the price changes. Although the price increases were in fact large, implementation was not so rapid as the terminology of "bangs" or "shocks" would suggest. The liberalization was controversial at the time, but without doubt necessary to stave off full scale collapse of the food economy later in 1992 (Morduch et al, 1994). Over the vast territory of Russia, regional authorities had limited understanding of the directives from the center, and considerable scope to set their own policies. None of the institutional infrastructure to ease the implementation of price liberalization was in place at the time. Most crucially, no safety net programs, such as food stamps or transfers, were operative to cushion the impact on the poor and vulnerable. The mixed price regimes that emerged at the regional level (greater flexibility combined with retention of some fixed prices) created an economic landscape that was somewhat chaotic, but also provided a degree of protection for those most vulnerable to the higher prices.

The administered pricing system prior to liberalization had created multiple marketing channels and multiple prices for the same goods. Limited quantities could be purchased in state stores at the formal price through queuing, and the poorest did so. Higher income shoppers could pay higher prices "out the back door," through special arrangements, or by shopping at the collective farm markets that had supply at higher prices. The liberalization merged the separate marketing channels and closed the "back door," with the result that prices rose most for the poorest consumers. Nonetheless, without the steep rise in prices the poor would have fared even worse, since a full-scale collapse would have emptied the state shops, while products would have continued to flow to some degree through the higher priced channels.

The higher food prices led to calls that wages be indexed to a consumption basket. Wages did increase, and this cushioned the impact for many households. Morduch et al (1994) argue that wage indexation probably reduced the welfare of the poorest, for whom targeted transfers would have been the preferred instrument. Gardner and Brooks (1994) examined the regional dispersion of food prices in the nine months following liberalization to determine whether evidence of incipient market integration could be discerned. They found price movement, but little integration. They concluded that (i) the fact that prices were liberalized before the retail sector was privatized or restructured and (ii) the differing price policies of regional and local authorities slowed market integration and impeded the gains that could have accrued from it. 
With better planning and a fuller array of institutions to facilitate implementation, the price liberalization could have proceeded more smoothly and yielded more and faster benefits. It accomplished the main objective, which was to prevent full scale collapse of the distribution system in 1992. Consumers stopped hoarding and flows of product from surplus to deficit regions renewed. Over time regional and national policies became more closely aligned and the processing and retail enterprises restructured, but the fuller array of benefits from price liberalization emerged only over time.

The experience in Eastern and Central Europe differed from that in Russia and other parts of the FSU. Privatization and restructuring of the retail and processing elements of the agri-food system proceeded more rapidly, although still with some delay. Changes in retailing and particularly the expansion of supermarkets starting in Poland, Hungary, and the Czech Republic changed procurement relations within the agrifood system and transmitted new prices along value chains (FAO/EBRD 2005).

\section{Lesson 3.}

\section{Consumers in Russia expected the transition to bring improvements in their welfare and felt be- trayed when it did not.}

Consumers watched with palpable relief in early 1992 as grocery stores began to restock empty shelves, but then recoiled in shock at the new prices. A consuming public little prepared to understand the reforms had expected shortages to disappear but prices to remain as in the old days. The economic facts of agricultural subsidization under the prior regime had not been publicly discussed, and people had no way to know that the old prices were highly distorted and unsustainable. The Nobel prize-winning author Svetlana Alexievich in her Secondhand Time: The Last of the Soviets captures the sense of betrayal about food prices and how it flowed over to disillusionment with the reforms in their entirety. The high food prices added to despair caused by loss of jobs, late or partial payment of wages, and the periodic destruction of savings with devaluation of the ruble and introduction of new national currencies in the former republics. People associated the hardship with the reforms and the new political structures, rather than correctly perceiving the degree to which the old system had excavated the hole into which the countries plummeted during the transition. In a political environment with well-established political parties, the disillusionment with reforms would have resulted rapidly in a populist reaction that empowered leaders willing to offer empty promises to restore prior standards of living. Russia's political reaction was somewhat delayed, and the replacement of reform-minded political leaders with more conservative and authoritarian politicians came only later.

In the Baltic states of the FSU, popular movements for independence and reform in the several years prior to the collapse had better educated the public about the problems of the last years of Soviet economic management. The political mobilization created positive anticipation of closer links with Europe and escape from a half century of Soviet domination. People better understood the derivation of 
the hardship of the transition and the prize that would come from accepting it and moving toward a rapid recovery. The popularity of political independence and the opportunity to orient toward the West, even among many Russians who had settled in the Baltics, created a context in which people were willing to accept economic hardship in the interest of political and economic reforms.

The situation in Central Asia was again quite different. Independence offered little obvious benefit to the general population, and instead created opportunities for the indigenous elite to consolidate power and increase rent seeking. Central Asians accepted the hardships of the transition because they had little choice not to.

\section{Lesson 4.}

\section{Household plots rose in importance for food security, but their managers received little direct assistance even as their share of production rose.}

The pre-transition farm structure in the Soviet Union consisted of state farms, collective farms, and household plots of families with members employed on the state and collective farms. Many urban families also maintained recreational "dacha plots" like hobby or victory gardens elsewhere (Brooks et al, 1996). The household plots on the state and collective farms had always been an important source of food and contributed a significant share of overall production, in part because they specialized in high value fruits and vegetables, cut flowers, and livestock products. In January 1991 household plots in Russia represented 1.4 percent of landholding and produced $26.6 \%$ of the value of gross output (Lerman and Brooks 1996, Rada et al 2017). By January 1994, the area under household plots had increased to 2.8 percent of total landholding (as the overall area of agricultural land declined by about 1 percent) and the share of output had risen to 43.8 percent (of a total that declined by a third over the period). Thus household-based small-scale production rose (absolutely) slightly over this period immediately after the collapse and came to represent an increased portion of a declining total.

Rural households had always depended on the plots. As shortages worsened before the collapse and prices rose after it, urban households increasingly turned to rural relatives and expanded their own dacha plots. Employees of state and collective farms could source inputs from the large farms as they always had, either through purchase, exchange of services, or pilferage. But as the state and collective farms cut back on purchase of fertilizer, tractor fuel, and other inputs the traditional flow from the farm storehouses to the plots dried up. The fact that output on the plots increased only slightly despite roughly a doubling of area suggests that they, like the larger farms, were constrained in access to inputs. The international assistance effort could have helped with supply of seeds, fertilizer, and other inputs for the small-scale household and dacha sectors, but did not, perhaps because this was not a priority of the Russian government at the time. 
With increased reliance on household and dacha plots, urban relatives lugging sacks of potatoes and cabbages back to city apartments and rural people seeking to sell their produce on the sidewalks of towns and cities faced challenges in transport. A recognition of the increased importance of own supply and the marketing channels associated with it and modest measures to assist could have helped.

\section{Lesson 5.}

The devaluation of the ruble in August 1998 and its floating as of September 1998 were more effective than any other measures in arresting the decline in agricultural production and food processing.

In August 1998, after recording its first year of positive economic growth since the fall of the Soviet Union, Russia was forced to default on its sovereign debt, devalue the ruble, and declare a suspension of payments by commercial banks to foreign creditors. On August 13, 1998, the Russian stock, bond, and currency markets collapsed as investors feared that the government would devalue the ruble, default on domestic debt, or both. Over a period of about a year between August 1998 and September 1999, the ruble depreciated 6-fold, from 5 to the dollar to 30, as shown in Figure 2. The devaluation was necessitated by a combination of low oil prices, lagging tax collection, mounting debt, and speculative action against the ruble with costly defense by the CBR. The financial crisis wiped out the savings of many ordinary people (again) and reimposed hardship when prospects for recovery had started to look promising.

Figure 2: Devaluation of the ruble with the economic crisis of 1998

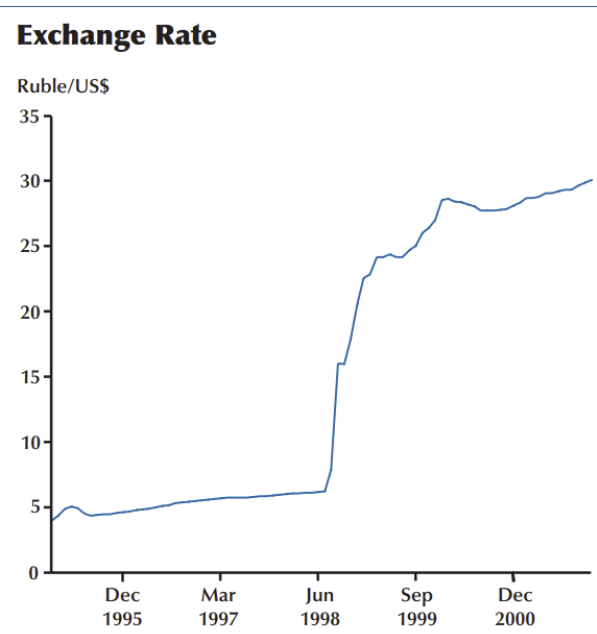

SOURCE: IMF (end of period data). 
The devaluation shifted food consumption to products of domestic origin, and away from the European imports that had been popular with middle and high-income consumers. Concurrently many consumers were coming to the conclusion that they actually preferred the products that they knew from childhood over the fancy European brands. With a shift back to known local brands, local production increased and both farms and processors were able to attract investment. The turnaround in output while inputs continued to decline led to an inflection point and subsequent growth in TFP, as shown in Figure 3 below.

Figure 3: Russian Production, Inputs, and TFP during the transition

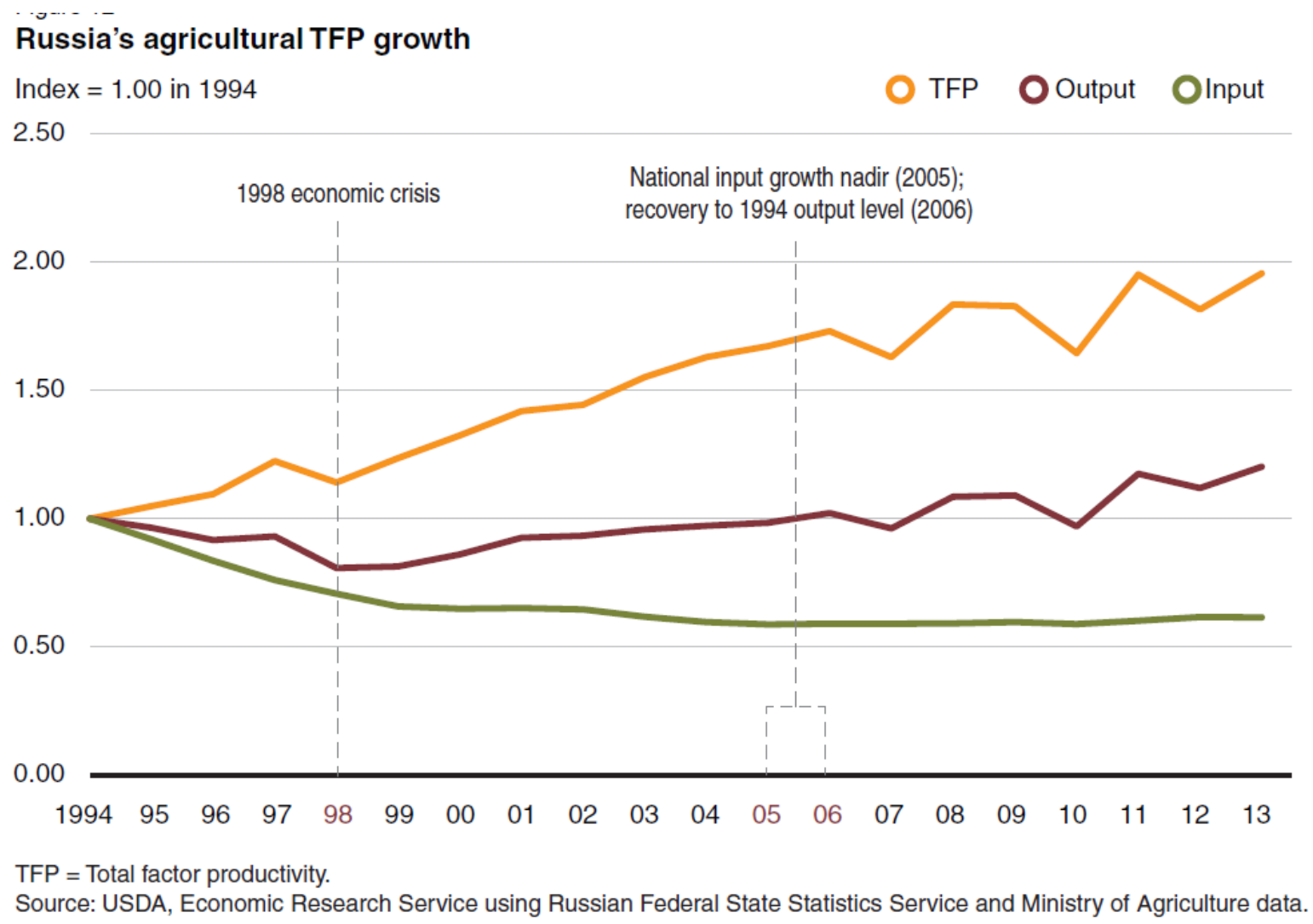

From Rada et al, 2017.

\section{Lesson 6.}

Changes in land ownership and farm structure varied widely across countries, reflecting historical memory of land holdings and constraints to establishment of new farms. Little active land hunger of the kind associated with traditional programs of land reform propelled the process, although restitution was popular when offered.

Changes in land ownership, farm structure, and the functioning of land markets varied across countries, with variation persisting over time (Swinnen et al, 2015). In much of Eastern and Central Europe 
and the Baltics, the shift to private ownership of land and dismantlement of the large farms proceeded rather quickly (Brooks and Lerman, 1994). Programs of restitution allowed families to reclaim land owned prior to nationalization and collectivization. State farms (in contrast to collective farms) in Eastern and Central Europe went through a different process of privatization, since most were formed on land owned by institutions, such as the Church, rather than families. Where restitution was allowed, families actively sought return of their land even if the claimants had little intention to farm. In Poland most of the land remained privately owned and operated throughout the socialist period. Land markets were slow to emerge, with resulting halting consolidation of fragmented holdings created during restitution and limited transfer to people actively farming commercially who wanted to enlarge their properties.

The state and collective farms of Russia, Ukraine, and Central Asia were converted into shareholding companies with shares distributed among employees and members of collectives. In theory shareholders could take the value of their shares in land and remove it from the parent farm to establish a private farm. Few chose to do so (Brooks et al, 1996). Reorganization and restructuring through distribution of shares resulted in a slow breakup of the parent farms, and most remained largely as they were. The former farm administrators in many cases consolidated ownership in the early years by buying up shares of employees. When farm profitability improved after 1998, the new owners were in a position to shift to commercially viable operations.

In Moldova the state and collective farms went through a similar process of restructuring through shares, but more shareholders opted to exit with land, perhaps because they were well aware of the process of restitution proceeding across the border in Romania. After an initial period of slow exit similar to that in Russia and Ukraine, the pace increased in 1996 as members sought to secure good land before it was all allocated. Restructuring in Central Asia had to take into account high population density in some areas and allocation and management of large-scale irrigation (including investment required for deferred maintenance) in others.

Changes in land ownership and farm structure throughout Eastern and Central Europe and the former Soviet Union took place in an environment of low or negative profitability with a need for massive reinvestment, change in technology, and adjustment in the product mix. Countries of Eastern and Central Europe restored the entire agrifood system more rapidly than was the case farther east and strengthened ties with European markets. Candidates to join the EU also had access to funds for investment to speed the emergence of functioning markets (Swinnen and Vranken, 2009). Restructuring in Russia, Ukraine, and Central Asia took place in a less conducive environment with proportionately less external support. Where land reform and farm restructuring are envisaged as part of a process of transition, demand for land to farm and the conditions under which farming can be profitable should be assessed to determine prospects for successful reform. 


\section{Lesson 7.}

Privatization of input supply, retailing, and food processing can be undertaken in a number of ways: case by case through auction; distribution of shares to employees; distribution of shares to suppliers; mass privatization through distribution of vouchers to the general public that can be redeemed against shares in companies; or "spontaneous privatization" (a euphemism for the seizure of ownership by management). Spontaneous privatization has obvious drawbacks in terms of fairness and equity, but among the other approaches, speed seems to be more important than technique.

Slow privatization of the off-farm elements of agrifood systems can distort incentives for production, block transmission of price signals, and encourage asset stripping by the former managers. Although the privatization was faster in Eastern and Central Europe than in Russia, and faster in Russia than in Central Asia, nowhere was it fast enough to avoid problems. Governments in many cases hesitated to shift storage and processing of strategic commodities (e.g., grain, sugar) and inputs, such as fertilizer and seed, into private hands out of concerns for food security and monopoly power. Absence of an effective legal framework enforcing bankruptcy coupled with regular debt write-off allowed state-owned enterprises to postpone privatization. Privatization of small businesses proceeded more rapidly than large, in part due to concerns about job losses associated with restructuring of the large enterprises. When profitability improved in Russia after the devaluation of 1998, privatized companies became more attractive and investment to fund technical renewal increased.

Privatization of state-owned enterprises in the agrifood sector formed an important component of the structural adjustment programs in Africa south of the Sahara in the 1990s. Some of the challenges can be seen, for example, in the completion report of the Agricultural Sector Management Project that supported reforms in Tanzania. Budgetary exigencies motivated the privatization, and the Ministry of Finance pushed the process, often over reluctance or objection from Ministry of Agriculture. Persistent pressure from the Ministry of Finance seeking to remove loss-making enterprise from the public budget led to speed and a pace of privatization not replicated in other dimensions of agricultural reforms (such as regulatory reform or restructuring of the ministries) that remained largely within the purview of Ministry of Agriculture. The latter reforms would have improved the performance of the sector but yielded little immediate budgetary relief (World Bank, 2001). The haste of the Ministry of Finance to privatize was not paired with follow-through to assist with reinvestment and complementary measures that would have contributed to success of the newly private enterprises.

Privatization generates constituencies in favor and in opposition. Understanding the constituencies can help build coalitions of support for reforms, but the objectives of those supporting privatization may not align fully with the approaches best suited to promoting successful reforms. 


\section{Lesson 8.}

The predominant source of capital for operating costs and investment in improved technology must be private. When agriculture is unprofitable (for example, due to exchange rate effects) and real interest rates are high (greater than 10 percent annually), access to private capital is not likely. Under these circumstances, farm and agrifood enterprises will show little response to reforms even if the reforms are well designed and appropriate.

In Russia prior to the devaluation of 1998 , farms and much of the processing sector were unprofitable and real interest rates were high. Farms had little access to capital but needed it to remain in operation. Various programs of preferential credit channeled funds to farms that were subsequently unable to repay even preferential loans. The government was unwilling to impose widespread bankruptcy on enterprises engaged in primary production, and therefore undertook successive waves of refinancing and debt write-off. The prior subsidies to agriculture before the collapse thus continued in diminished form through the state's interventions in the banking system. The cycles of preferential credit and write-off benefited large farms and companies that were managed much as they had been in the past, thereby forestalling or delaying genuine restructuring. Smaller individual farmers who took land out of the state and collective farms under the restructuring programs did not have access to credit under the same conditions.

The willingness of the Russian state to carry and write-off agricultural bad debt between 1991 and 1998 contrasts with the urgency with which Ministries of Finance in Africa south of the Sahara sought to divest the debt obligations of state-owned enterprises. Depending on the size of the sector, the magnitude of accrued debts, and the underlying profitability of the sector (and appeal to private investors), the financing needs of the agricultural sector during and after a transition can impede stabilization of the banking system and macroeconomy more generally.

\section{Lesson 9.}

Investment in essential public goods and services lags when a transition is forced by economic crisis, but maintenance of key goods and services is essential for success.

A transition brings drastically different rules, incentives, and opportunities. Economic agents that survive and thrive alter production technology, product mix, input use, and marketing. Enterprises operating under drastically different rules benefit from advice and access to new technologies; in short, the services provided by extension, agricultural research, pest monitoring, weather forecasting, market outlook summaries, and other. During China's reforms of the 1980s after introduction of the household responsibility system in 1978, both extension and agricultural research expanded in support. Investment in these key public services increased and remained high, and institutional reforms to position the services to meet the needs of producers and other agents followed with some delay (Huang and Rozelle, 
2018). The fact that China's transition was launched in an environment not characterized by acute economic crisis made this constructive approach to complementary services possible.

In Eastern Europe and the former Soviet Union, in contrast, political upheaval and economic crisis pushed attention to agricultural services out of the picture at a time when they were much needed (Brooks and Nash, 2002). Governments had historically supported agricultural research, although the profession in the Soviet Union never fully recovered from the politicization of science under Stalin. At the end of the 1980s research institutes were overstaffed relative to those in Europe and North America and poorly linked to global scientific developments. Since the collective and state farms had agronomists and veterinarians on staff, there was no separate extension service.

With the transition and economic crisis, the research institutes retrenched by cutting operating funds but retained redundant staff even if they could not pay them. The advisory functions formerly inhouse within the state and collective farms fell victim to disorganization during the restructuring. During the crucial years of the early 1990s as production plummeted, research and advisory services fell into disarray and were not restructured until later.

\section{Lesson 10.}

\section{A transition undertaken when the economy faces triple demands (stabilization, improved effi- ciency, and diversification away from oil) is more difficult than one with only one or two of these objectives.}

The assertion stated above (lesson \#1) that context matters relates largely to the historical legacy framing the conditions under which the transition unfolds (e.g., net taxation of the sector vs. net subsidy; the impact of the incentive environment). Forward projections also matter. In the case of the African transitions implemented through structural adjustment, the objective was largely to reestablish macroeconomic stability within an envelope of sustainable debt and feasible budgets. China's transition developed initially organically when it became apparent that limited experiments with the household responsibility system could generalize to a significant improvement in agricultural performance. Complementary measures then supported deepening of the agricultural reforms and diversification of the economy, with well-known impacts on wealth, growth, and poverty reduction. Although China's transition was not explicitly designed as such, it became a means for agriculture-led transformation and industrialization of a predominantly agricultural economy.

The transition in the former Soviet Union and Eastern Europe became necessary when low oil prices made it no longer feasible to cover the costs of the inefficient economic system. A significant portion of the high costs was generated in the agricultural sector, but few countries were predominantly agricultural. The transition should have accomplished three tasks: reestablished stability, improved the 
overall efficiency of the economy, and reduced the heavy dependence on oil exports. The first two were accomplished over time with price reforms, opening to trade, privatization, and related legal and regulatory reforms. The third task was deferred as oil prices recovered after the 1998 financial crisis and continued at high levels for the next twenty years. The economy has diversified very little away from dependence on oil exports. The transition in Russia is therefore partial. Difficult as it was, it would have been more challenging had oil prices not recovered.

From the vantage point of 2020, a twenty-year period of high future oil prices seems very unlikely. A country dependent on oil exports, such as Venezuela, and undergoing a transition therefore faces the three-fold imperative to achieve macroeconomic stabilization, improve economic efficiency, and diversify away from dependency on oil. Agriculture and the agrifood system can play a constructive role, and a well-designed set of policies to effect reforms should be pursued. These should be seen within a larger picture of the evolution of the economy to reduce dependence on oil. Although agriculture and the agrifood system will not substitute for the past dominance of oil, a well-performing sector can contribute to employment, revenues, food security, and growth.

Perhaps the most important lesson of the transitions in Eastern and Central Europe and the former Soviet Union is the need to educate the public about what is happening, why, and what options for the future are under debate and consideration. The new leaders in the Baltic states were able to bring their populations along with the reforms in part because the appeal of closer relations with Europe was very strong, but also because people were informed. For a very brief period in 1992 Russian television had excellent programming with coverage of current events and open policy debates. This did not last long and was in any case not sufficient to counter the disillusionment that Alexievich recounts.

No reforms will counter or overcome the drop in income that oil-dependent countries face when oil prices fall. This is a difficult message for citizens to accept. It is nonetheless one that they should hear, along with clear explanations of steps being taken to restore stability, improve economic efficiency, and reorient the economy toward a more sustainable foundation. In the case of Venezuela, the economic crisis and collapse in incomes has happened prior to the transition. Hardship may therefore be associated in the public understanding with the old regime rather than the coming reforms. This may incline citizens to accept and even welcome the needed changes. In a global environment of resurgent populism, however, the risk of public rejection of reforms remains high. Well designed and implemented reforms, external assistance to cushion the hardship (and not only on the most vulnerable), and consistent messaging to inform the public will be needed. 


\section{ABOUT THE AUTHOR}

\section{Karen Brooks is an Adjunct Professor at the Global Human Development Program, School of Foreign Service, Georgetown University.}

\section{REFERENCES}

\section{Bibliography}

Alexievich, Svetlana. 2016. Secondhand Time: The Last of the Soviets (translated by Bela Shayevich) Random House.

Brooks, Karen. 1991. "Decollectivization and the Agricultural Transition in Eastern and Central Europe," World Bank Agriculture and Rural Development Department Policy, Research, and External Affairs Working Papers \#793, October 1991.

Brooks, Karen and Lerman, Zvi. 1994. "Farm Reform in Transition Economies," Finance and Development, Vol. 31, No. 4, December 1994, The World Bank and The International Monetary Fund, Washington, DC.

Brooks, Karen; Krylatykh, Elmira; Lerman, Zvi; Petrikov, Aleksandr and Uzun, Vasilii. 1996."Agricultural Reform in Russia: A View from the Farm Level," World Bank Discussion Paper 327.

Brooks, Karen and Nash, John. 2002. "The Rural Sector in Transition Economies," Handbook of Agricultural Economics, Volume 2, Edited by B. Gardner and G. Rausser, Elsevier Science B.V.

Chiodo, Abbigail J. and Owyang, Michael T. 2002. "A Case Study of a Currency Crisis: The Russian Default of 1998," Federal Reserve Bank of St. Louis Review, November-December 2002.

FAO. 2005. "Cooperation Programme Central and Eastern Europe: Impact of Food Retail Investments on the Food Chain", FAO Investment Centre / EBRD Report Series N. 7. February 2005

Gardner, Bruce L., and Brooks, Karen 1994. "Food Prices and Market Integration in Russia: 1992-93." American Journal of Agricultural Economics, vol. 76, no. 3, 1994, pp. 641-646. JSTOR, www.jstor.org/stable/1243681. Accessed 3 Nov. 2020.

Huang, Jikun and Rozelle, Scott. 2018. "China's 40 years of agricultural development and reform," in Garnaut, Ross, et al., editors. China's 40 Years of Reform and Development: 1978-2018, ANU Press, Acton ACT, Australia.

Koester, Ulrich and Brooks, Karen. 1997. "Agriculture and German Reunification,” World Bank Discussion Paper No. 355, World Bank, Washington, D.C.

Lerman, Zvi and Brooks, Karen. 1996. "Land Reform and Farm Restructuring in Russia," Problems of Post-Communism, November-December 1996.

Rada, Nicholas; Liefert, William; and Liefert, Olga. 2017. "Productivity Growth and the Revival of Russian Agriculture", ERR-228, U.S. Department of Agriculture, Economic Research Service, April 2017.

Swinnen, Johan F. M.; Rozelle, S. 2006. From Marx and Mao to the market: The economics and politics of agricultural transition. Oxford University Press, U.K.

Swinnen, Johan F.M. and Vranken, Liesbet. 2009. Land \& EU Accession: Review of the Transitional Restrictions by New Member States on the Acquisition of Agricultural Real Estate. Land \& EU Accession, CEPS Paperbacks, European Community, 2009, Available at SSRN: https://ssrn.com/abstract=1331366

Swinnen, Johan; Van Herck, Kristine; Vranken, Liesbet. 2015. "Twenty-Five Years of Transition and European Integration: Some Observations on the Governance of Land Markets in an Integrated Europe," Studies on the Agricultural and Food Sector in Transition Economies Edited by Leibniz Institute of Agricultural Development in Transition Economies IAMO Volume 79, Leibniz.

World Bank, Implementation Completion Report (IDA-25370) on an IDA Credit in the Amount Of Us\$24.5 Million to the Republic of Tanzania for an Agricultural Sector Management Project - ASMIP (Credit No. 2537-TA). Report No. 23354, 2001.

Funding for this work was provided by the collaborative work with Michigan State University, financed by USAID. This publication has not been independently peer reviewed. Any opinions expressed here belong to the author(s) and are not necessarily representative of or endorsed by IFPRI.

INTERNATIONAL FOOD POLICY RESEARCH INSTITUTE

A world free of hunger and malnutrition

IFPRI is a CGIAR Research Center 